White Saris and Sweet Mangoes 
The publisher gratefully acknowledges the generous contribution to this book provided by the General Endowment Fund of the Associates of the University of California Press. 


\section{White Saris}

and Sweet Mangoes

Aging, Gender, and Body in North India

SARAH LAMB

University of California Press

BERKELEY LOS ANGELES LONDON 
University of California Press

Berkeley and Los Angeles, California

University of California Press, Ltd.

London, England

(C) 2000 by the Regents of the University of California

All photographs taken by author

Grateful acknowledgment is made for permission to reprint portions of the author's earlier articles: "Aging, Gender and Widowhood: Perspectives from Rural West Bengal," from Contributions to Indian Sociology 33, no. 3 (1999), and "The Making and Unmaking of Persons: Notes on Aging and Gender in North India," reprinted by permission of the American Anthropological Association from Ethos 25, no. 3 (September 1997), not for futher reproduction.

Library of Congress Cataloging-in-Publication Data

Lamb, Sarah

White saris and sweet mangoes : aging, gender, and body in North India / Sarah Lamb.

p. $\quad \mathrm{cm}$.

Includes bibliographical references and index.

ISBN 0-520-22000-5 (cloth : alk. paper)-ISBN 0-520-22001-3 (pbk. : alk. paper)

1. Aged-India-Bengal-Social conditions. 2. Aging-IndiaBengal-Family relations. 3. Aged-India-Bengal-Psychological aspects.

HQ1064.14 L36 2000

305.26'0954'14-dc21

$99-088195$

Manufactured in the United States of America
$09 \quad 08 \quad 07 \quad 06$
10 $9 \begin{array}{lllll}9 & 8 & 7 & 6 & 5\end{array}$

The paper used in this publication meets the minimum requirements of ANSI/NISO Z39.48-1992 (R 1997) (Permanence of Paper). 